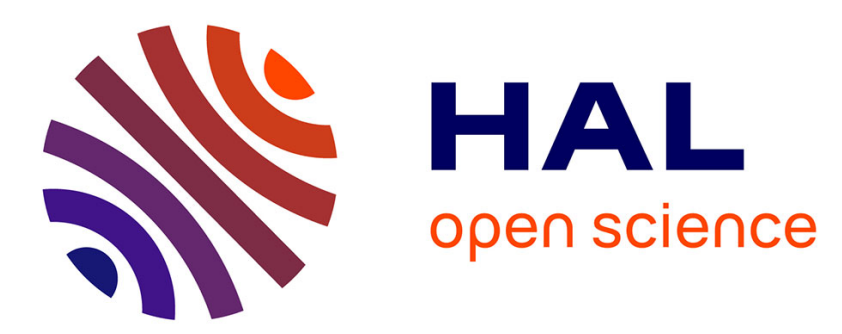

\title{
Studying religious mobility: pilgrimage, shrine visits and religious tourism from the Maghreb to the Middle East
}

\author{
Katia Boissevain
}

\section{To cite this version:}

Katia Boissevain. Studying religious mobility: pilgrimage, shrine visits and religious tourism from the Maghreb to the Middle East. New Itineraries and Pathways in Pilgrimage studies, 2017. halshs01791452

\section{HAL Id: halshs-01791452 \\ https://shs.hal.science/halshs-01791452}

Submitted on 14 May 2018

HAL is a multi-disciplinary open access archive for the deposit and dissemination of scientific research documents, whether they are published or not. The documents may come from teaching and research institutions in France or abroad, or from public or private research centers.
L'archive ouverte pluridisciplinaire HAL, est destinée au dépôt et à la diffusion de documents scientifiques de niveau recherche, publiés ou non, émanant des établissements d'enseignement et de recherche français ou étrangers, des laboratoires publics ou privés. 
Studying religious mobility: pilgrimage, shrine visits and religious tourism from the Maghreb to the Middle East

Katia Boissevain

Religious pilgrimage and holy visits to sanctuaries are a widespread phenomenon in the Maghreb and Middle East. Hajj (pilgrimage to the holy city of Mecca), on the one hand, and ziyara (visits to shrines), on the other, are seen by most people, devout or not, as distinct social practices and not to be compared or thought in relation to one another. Nevertheless, anthropologists and historians of the Muslim world have shown how the two share a common symbolic history and similar practices. The numerous local pilgrimages are always emically considered secondary to the pilgrimage to Mecca but despite the clear distinction in local discourse, they may under certain conditions be presented as pilgrimages of substitution. Consequently, the notion of pilgrimage in the Muslim world, whether Arab or not, has long been studied through the model of and in relation with hajj. While people prepare throughout the year for hajj, from Morocco to Iran and further east, in urban or rural settings, holy men and women are visited and worshiped at any time for the intercession they provide. Hence, although hajj and ziyara can be studied for themselves, they should not be totally separated from one another. Every year millions of Muslim pilgrims and/or visitors 'hit the road' and this mass movement has been focus of a thriving scholarly field ever since the early twentieth century.

In this chapter I will begin by considering how scholars have underlined the complex articulations and interplay between hajj and ziyara. I will then retrace the ways in which the social phenomenon of pilgrimage and local shrine visit has been studied in this region of the world according to different scholarly traditions. Despite the geographical and historical divide between the eastern and western area of the region, called in pre-independence 
terminology North Africa and the Near and Middle East, a common denominator is that the founding works of colonial ethnographers mainly explored rural settings and when studying religion, they did so from the angle of religious rituals. By the 1970, the focus changed from religious 'survivals' (thought to be found in the countryside) to that of 'popular Islam', which took urban settings into consideration. Anthropologists of religion began to engage with sociological considerations and 'popular Islam' came to mean the religion of poor, illiterate people.

After a post-independence decline during the 1960s and 1970s, historians and anthropologists have taken a renewed interest in sacred sites and sainthood across the Maghreb and Middle East. They have reexamined colonial historiography and unlike, for example, the French author, Émile Demerghem, they no longer envisage the topic as solely a subject relevant to religious studies or as folklore but also a field of inquiry that is part of a wider social and political picture. This approach was advanced in the important study by Kerrou (1998), who examines the basis of the saint's authority, and Mayeur-Jaouen (2004), whose case study of Sayyid al Badawî of Tanta (Egypt) is set within centuries of Egyptian ordinary religion. Finally, I will show how scholars have explored the development of religious tourism and cultural heritage and its relationship with such important processes as globalization, the promotion of regional Islam and more generally, local politics.

\section{Hajj and ziyara: a complex interplay}

In an important book, Chiffoleau and Madoeuf (2005), insist on the various types of pilgrimage in the Middle-East (hajj, ziyara, mouled, mawasim, Muslim, but also Jewish and Christian) and the links between them, showing them in all their diversity in their relation to the public sphere, be it political or economic. The hajj or Great Pilgrimage is the last of the 
five pillars of Islam ${ }^{1}$. It takes place during the $12^{\text {th }}$ month of the Muslim year - Dhûl-hijja (pilgrimage month) - and in recent years it involves around three million pilgrims in Mecca. The holy city is also the place of the small pilgrimage or umrah, which can be accomplished at any time of the year. The hajj is completed over five days and all participants, men and women, old and young, perform the same rites as equals. For example, the Great Mosque of El Haram at Mecca is the only place in the Muslim world where men and women pray side by side.

Besides this major pilgrimage, numerous rural and urban shrines, called zawiya-s, welcome pilgrims and visitors on a weekly basis, for rituals called ziyaras (visits), or on special dates, such as the birth of a particular holy man or (less frequently) woman. These celebrations are called moussem in the Maghreb or mawasim in the Machreq, in Egypt, (Mayeur-Jaouen 2004, 2005, Reysoo 1991) and are often (but not systematically) linked in some way to a Sufi tariqa (brotherhood), and people from all walks of life and social background would potentially pay a visit. Zawiya-s may contain the tomb (qbar) of a holy person, where the body is present, or most often, a catafalque (thabût), an empty wooden box, covered by colourful material and religious objects such as the Koran, candles, oil and water from the well, where the holy person's blessing (baraka) is intense. Their architecture varies from elaborate buildings with a great number of rooms to welcome visitors who wish to spend a few nights near the saint, a prayer room, patios, kitchen and slaughtering courtyard (madhbah), sometimes kuttâb (schools for religious education), or a single little square room with the thabût in the middle. All of these buildings are crowned by a dome or qubba, which giving a distinctive look to Muslim shrines in the region.

\footnotetext{
${ }^{1}$ After shahada (profession of faith), salat (prayer), ramadhan (month of fasting) and zakat (alms giving).
} 
These mawasim and mawlid-s have been compared with medieval feasts and we have vibrant descriptions of these occasions in Egypt (MacPherson 1941, Lane 1963, Madoeuf 1997, Mayeur-Jaouen 1994, Chih 2000). During this special time, visits to the saint's tomb are continuous and disciples, pressed by the crowd, have to make their way to the maqsûra, the fence which most often protects the catafalque of the saint. Once there, the visitor recites the fatiha (opening verse of the Koran) and while kissing the fence or rubbing his hands or clothes for baraka, makes a petition to the saint (health, fertility, good fortune...). While the wish is formulated, there is a promise of a gift in return. According to the space and the architecture, the disciples will walk anti-clockwise (circumambulation) round the tomb. The same ritual is accomplished around the Ka'ba in Mecca during the hajj and as Mayeur-Jaouen writes (1994, 372):

Silently, implicitly, ziyara itself is linked to hajj: today, we hang ex-votos on the shrine's walls, photos of the Ka’ba or the Prophet's tomb. The decoration we find in so many Muslim interiors is inoffensive but it definitely evokes the hajj at the heart of the ziyara.

The ritual parallels between hajj and ziyara can be found elsewhere: circumambulation, incubation, touching the tomb (or the black stone in Mecca) and drinking the water from the sacred well. Many places in the Muslim world clearly work as substitute destinations to Mecca. The volume of articles collected by Chambert-Loir (1995) on saint worship mentions a few of them from the Maghreb to Asia, such as the mosque at Kairouan in Tunisia which, if visited seven times, equates to a full hajj.

Besides the parallels between hajj and ziyara, it is also interesting to note the links between them: for example, the gesture of bringing back a gift from hajj for a local saint seems to be increasing. This ritual symbolically brings the two places in relation through gifts 
which can be made of carpets, chandeliers, religious paintings to be hung on the wall or other goods which fall in the 'household' category of objects. We must add to these rituals that of bringing some religious paraphernalia back home to friends and families (water, rosaries, incense, small trinkets).

Nevertheless, the fact that ziyarat and hajj practices are intertwined should not hide the fact that visits to local shrines are often disapproved of on religious grounds. There is an inherent tension with regard to the practice of visiting shrines because it contradicts the idea of the unity of God and the impossibility to associating anyone or anything with Allah. Such practices are called shirk (associationism) and bida' (innovation). Similarly, deciding that some places are holy and worth a devotional visit because a holy person is buried there or because miracles have happened there due to a spring, grotto, tree or well, goes against the belief that the surface of the earth uniformly reflects Allah's power and benediction.

\section{A short history of spiritual mediation in the Muslim world}

The origin of such tensions is intrinsic to the ambivalence concerning the relationship between God and human beings in monotheist religions, unmediated and direct or eased along by the intercession of intermediaries (Brown 1984), in this context, walîs (male) or waliyas (female) close to God. The notion of sainthood is absent from the original teachings of Islam, which only recognizes God as 'holy’ (quddûs) (Andézian 2001) - a term referring to separation, transcendence and absolute purity. Goldziher (1971) underlines that the belief in the unity and absolute power of God, as well as that of the total separation between the human and divine world, does not leave room for intermediaries between Allah and human beings. In the beginning, even the Prophet Muhammad was seen as only a messenger, who did not have access to divine mysteries (Koran: XVII, 93 and XVIII, 110). On the other hand, the Koran 
does mention examples of pious men and women, who will benefit from a special place in paradise, but it specifies that this grace cannot be transmitted to humans.

In practice, Muslim society was quick to invent particular figures of men and women, who, sanctified while alive, are consulted as intermediaries between human beings and God and special rituals were developed such as visits, prayers, votive gifts and sacrifices. Their intercession was expressed through miracles during their lifetime and cults around them emerged after their deaths. Popular pressure imposed the idea of sainthood or holiness at a doctrinal level during the ninth century, when a change in the way the Prophet was represented occurred. Muhammad went from being seen as solely human to half human/half divine. This new representation of the Prophet coexisted with the belief in the unity of Allah and led to the veneration of his tomb and those of his family (Ahl al Bayt) and his Companions. As Chodkiewicz (1995) suggests, the cult of saints and the visits to their tombs can be seen as extensions of this devotion. In the beginning of the thirteenth century, the celebration of the Prophet's birth (mawlid-al-nâbi) was institutionalized and founders of Sufi turûq (ways, paths, brotherhoods) began to benefit from the same type of veneration. A collection of articles edited by Popovic and Veinstein (1995) retraces the different histories and particularities of the various important paths and saints in the Muslim world, some of which have given rise to on-going pilgrimages.

The doctrinal elaboration of the notion of sainthood (walâya) is closely linked to that of the place of the Prophet, therefore. Simultaneously close to human beings and Allah, the walî becomes an intermediary whose intervention calls on special rituals, such as shrine visits. This definition of sainthood and the ritual practices, which frame it, were continually discussed and contested. As early as the fourteenth century, Ibn Taymiyya criticized the criteria by which saints and their miracles (karamat) were recognized (even though he admitted the reality of men 'close to God', see Chodkiewicz 1995) and refuted the power of 
mediation of saints and prophets, which he called 'associationism' (shirk). By the eighteenth century with the Wahhabi movement, the discussion is amplified and gives way during the twentieth century to the salafiyya, a political, religious and cultural movement. Sufism, especially in its religious brotherhood variant, is the favourite target of this movement in their fight for a 'return to the original Islam of the pious founders'.

The confluence of the Salaf movement and the modernization of political and social structures in Muslim countries has severely impaired the practice of shrine visit, even though people still visit them on certain occasions. In Tunisia the historian Latifa Lakhdar (1998) explains that deep historical relations have been maintained between political power, 'ulema (sing. 'âlim), specialists in religious law and scriptures, and saints from medieval Ifriqiya until the early twentieth century. Green (1978) has also shown how many families could have 'ulema among its members, as well as prominent cheikh-s of Sufi brotherhoods, involved with the mystical side of religious practice. This social interweaving explains why the ruler or Bey of Tunis continued up to the country’s independence in 1957 to visit sacred shrines, practice ziyara, and value the protection of holy figures. Furthermore, in the 1920s the Bey, advised by the 'ulema, refuted Wahhabi ideology, especially in its anti-sainthood guise. Up to the early twentieth century he would visit all the capital's important saints on various religious occasions, such as the Aïd el Saghir, which marks the end of the fasting month of Ramadan. These religious journeys were at once ways to put himself under their protection while reactivating, through his worship, the saints’ power over the territory of Tunisia, as if a protective mesh was thrown across the land.

\section{Studies of the hajj as template or mould}

Many nineteenth century scholars became fascinated by Mecca and its ‘exclusive' dimension as a city solely reserved for Muslims. This Orientalist fascination led to incognito' travelers 
such as Burckhardt (1814), Sir Richard Burton (1853) or Snouck Hurgronje (1885), who gave detailed accounts of the rituals of the Great Pilgrimage and daily life in Mecca. Since then, description or analysis of hajj and umrah at Mecca has taken two forms. Firstly, from an insider point of view, Muslim anthropologists have analyzed the complete experience, coming from abroad and going through the complete ritual process. Hammoudi (2005) insisted on the personal and emotional experience intertwined with the globalized aspect of the event, while Saghi (2010) embarks on a sociological journey which takes the reader to Mecca while engaging with issues of religious anthropology and the anthropology of tourism. He argues that hajj and umrah now take on a different meaning compared with twenty years ago. What was once the pilgrimage of a life-time - which it still is for the older generation - is now sometimes a regular occurrence, motivated by a combination of religious fervor, desire for holiday break, and socially valorized activity. This is especially the case among the younger, wealthier generation, from Europe or the Muslim world's bourgeoisie.

Non-Muslim scholars, far from adopting the undercover position of their predecessors, assume a shift of object and, following Eickelman and Piscatori (1990) in their argument that the journey is part of the ritual, concentrate on the travelling process rather than the shrine itself. Sylvia Chiffoleau, for example, is a historian who was first interested in the medical supervision of the transnational event, and later, has worked on the international politics of pilgrim travel (Chiffoleau 2015), arguing that from the nineteenth century European colonial states were worried by the possible contamination of disease and Muslim ideas (from panArabism to Muslim Reformism). Others have analyzed the state and family politics at work in the organization of the event (Boissevain 2015), or study the hajj in terms of the relationship between the significance of pilgrimage for the religious lives of individuals and the wider contexts in which they are embedded (Buitelaar and Luitgart, 2015). 
Besides the pilgrimage to Mecca, important regular gatherings take place throughout the Muslim world and celebrate an intimate relationship with the Prophet, members of his family (Ahl el Bayt), or a saint. As we have seen, they are called mawlid-s (mouled-s in the Maghreb) and are yearly occasions. Fred de Jong $(1976,1999)$ dates this practice back to the Fatimid period when it was an aristocratic phenomenon but became more popular when the Mamelouks instituted the celebration and the term mawlid was extended to saints' birthday celebrations. Eric Geoffroy (1995) explains that the Sufis made an important contribution to the institutionalization of this ceremony as cheikh-s would bring along their numerous disciples.

\section{From religious ritual survivals to the social dimension of pilgrimage}

During late nineteenth century, French colonial administrators and European scholars documented religious organization and rituals in the Maghreb. Around the turn of the twentieth century major studies were written on the cult of saints, which included descriptions of the religious rituals, the organization of the brotherhoods and their relation to the territories and the central state. One example of these studies is Goldziher’s article entitled ‘le culte des saints chez les musulmans’ (1880). Catherine Mayeur-Jaouen states how fundamental his work has been, since up to the 1970s it shaped most of the research on pilgrimage to holy men and women in the Muslim world. His main idea was that of a continuity between the religion of the pagan Gods and the cult of saints, which were illegitimate additions to the pure and original Islamic religion.

Following in his footsteps, the central concern for anthropologists at this time was mainly to evaluate the type of political authority, which could be mobilized through the disciples. The 'nature' of the rituals was thought to be linked to the question of survivances (survivals) and what items could be detected in local customs from a distant Berber or Roman past. This concern gave way to very detailed ethnographies on such topics as 'magic and 
religion’, ‘weddings’ and ‘traditions’ (Depont and Coppolani 1897, Rinn 1884, Mouliéras 1899, Doutté 1909). These studies, conducted mainly in Morocco and Algeria, form the basis of later research, but at the time, they crystallized the idea of religious brotherhoods as potential resistance groups (against the Ottoman invaders and then the French). French Orientalists publicized the cult of saint under the name 'maraboutism', from the Arabic word murâbit. (Chabbi proposes that murâbit refers to its root rbt, which means 'tied to', 'attached', understanding walîs are 'tied' to Allah). Their main hypothesis was that these rituals should be understood as survivals of a pre-Islamic world, where wells, springs and grottos were worshipped behind the façade of Islam. An important analyst of the midtwentieth century Maghreb is Emile Dermenghem, who was sent to Algiers in 1942 for the development of the Islamic collection of the General Governor's library. This job enabled him to conduct fieldwork on local folklore over a number of years (1954).

By the 1960s both French and Anglophone anthropologists in the Maghreb had shifted focus from Algeria to Morocco (Geertz 1968, Gellner 1969, Jamous, 1981) and became interested in the local political dimension of religious authority. The issue was no longer the position of religious brotherhoods in relation with French colonial authorities, but rather the local rationalities of political action. Other scholars began to observe religion and visits to holy men in urban settings (Crapanzano 1973), analyzing ecstatic religious brotherhoods and possession cult rituals, such as the Hamadshas in Fès. This change in field occasioned a change in questioning too, since moving around urban localities led them to consider such issues as development, poverty, illiteracy in a literate context (the city), and eventually the question of gender. From the 1970s most studies saw visits to saint's tombs as the main expression of women’s religiosity. Provensal (1975), drawing on her research in Algeria, proposes that women play a more important role than men in the reproduction of these religious phenomena. Most of the time, these rituals appear to be autonomous from the men's 
observances and always on the margins (Mernissi 1977, Dwyer 1979), the main argument being that visits to saints are rituals, which enable forms of resistance against a patriarchal society. In associating ziyara-s with women's religiosity, the cult of saints is here clearly relegated to the realm of popular religion, is always acquainted with illiteracy and poverty, and is far removed from the scriptural world of men. ${ }^{2}$

From the 1970s through to the 1990s debates concerning the different levels of Islam, framed within the Great/Little tradition model, were fueled by researchers’ fieldwork experience and attempts to bring together male and female worlds. Nancy and Richard Tapper (1987), for example, were able to access and compare different gendered realms of Turkish society and thus re-evaluate the idea that local pilgrimages were specific realms of women's devotion. Reysoo (1991), in her work on Moroccan moussem, also noted how men and women's rituals during this type of pilgrimage interact and related to each other.

As Kerrou and Valensi have reminded us (Kerrou 1998) ziyara-s have been considered as a lesser form of religious practice and were associated with rurality, women adepts and popular classes. This approach was similar to the way Christianity was studied before Peter Brown (1984) demonstrated that this way of dividing the world was an elitist and static representation of Christian beliefs. Similarly, the perception of a radical opposition between two forms of Islam - that of the 'ulema on one side and of mystical Islam on the other - is incorrect. Firstly, among great Muslim thinkers, many were at once men of law and mystics (Ghazâli for example) and the presumed ‘illegality’ of certain ritual practices has been legalized by religious men in power during various periods (Andézian 2001, 19). Even

${ }^{2}$ For a helpful discussion of the anthropological literature on women and Islam, see Andézian, 1995. 
famous reformists, such as the Egyptian Mohamed 'Abduh, have expressed their attachment to Sufism.

Mystical rituals, as well as possession cults which take place in many shrines, can be analyzed through the question of territorial belonging and the debate about the relationship between religion and the nation during the 1960s, which was a time of national construction, after the struggles for independence I have moved this paragraph -WHERE? It is common for a local saint to be associated with a variety of territories, places and intellectual spheres. Often, a holy person belongs at once to both the town and the countryside, appears to be learned — through religious education acquired from a religious master — and mystical through direct initiation and contact with the divine. Often, the rituals performed in zawiya-s refer at the same time or alternately to the great scriptural tradition (through the performance of rites celebrating religious brotherhoods or tariqa-s) and/or to possession cult rituals, which refer to another dimension of religious tradition, that of jnûn and spirits. It is this complexity and mixture of genres, which is mainly criticized by contemporary reformist Muslims.

\section{Pilgrimage, holy visits and the wider issues}

Gradually, contemporary scholars are studying pilgrimage and holy visits to shrine from a broader perspective. While ritual remains an important issue, other aspects of visits to shrines are being considered, such as the journey to get there, the regional context in which the journey takes place, urban development and the political issues raised by these pilgrimage routes. Significant examples of this shift of preoccupation can be found in the volume edited by Eickelman and Piscatori, Muslim Travellers (1990), or Moussaoui’s work on the south of Algeria (2002), where the author includes in his analysis the question of space, mobility and sacrality. During the same period two important edited volumes appeared, which brought together chapters on saint cults across the Muslim world in order to underline both their diversity and common elements. The first was edited by Henri Chambert-Loir and Claude 
Guillot (1995) and the second was edited by Mohammad Ali Amir-Noezzi (1996) and stretches geographically as far as South East Asia. These volumes go beyond the study of rituals per se to examine other dimensions, such as the importance of local history in religious transformations.

Over the last thirty years there has been a renewed interest among historians and anthropologists in holy sites and sainthood across the Maghreb and Middle East. These studies have re-examined colonial historiography, but as a field of inquiry which engages with the wider social and political picture. The innovative feature of this research lies in its desire to take both sides of saint worship into account: analyzing not only the lives, histories and legends of saints through their hagiographies, for example, but also understanding the social issues involved through an exploration of the rituals practiced during the journeys to and time spent at the shrines (Kerrou 1998, Mayeur-Jaouen 2002, Amri and Gril 2007, Boissevain 2006). Hence, anthropologists see saint worship as a devotion to the divine and the holy person and an embodiment of social relations, while also taking into account the preoccupations of pilgrims and visitors. Scholars have underlined the multiple motivations for visiting a saint and the possible tensions or peaceful collaborations, which are at play between different groups in this locus of power (Aubin-Boltanski 2007, Albera and Couroucli 2012).

Furthermore, from a theoretical point of view, studies on pilgrimages in the region have been seen through three main perspectives - that inspired by Durkheim, where pilgrimage is understood as social cement, the Turnerian approach to pilgrimage as a search for communitas and the perspective, building on Eade and Sallnow (1991), where pilgrimage involves arenas for multiple and often conflictual discourses and practices. Of course, far from being mutually exclusive, these perspectives can and should be mobilized jointly to analyze pilgrimages in the most complete manner possible. 


\section{Heritage policies, religious tourism and religious practice}

From the 1960s, the general assumption in scholarly research on saint devotions, visits to shrines and local pilgrimages was that these practices would slowly disappear due to modernization, nationalism and the hegemony of religious reformism. Yet, while it is true that local pilgrimages have declined, they have not completely vanished (Luizard, 1993). As Mayeur-Jaouen states about the context of Egypt:

The success of Reformism has led, undoubtedly, to a greater moderation in religious practices. It has contributed to contain on the rural and the humble side, practices which Egyptians used to observe unanimously, such as the mouled. Yet, the tenacious resistances of devotions, their flexibility of adaptation to the Reformist's discourse, show their deep roots (1996: 131).

Elsewhere, from Morocco to Iran, new configurations have developed and given way to new hierarchies, with some major historical mausoleums maintaining their attractive power despite changing political forces. Yet, some shrines clearly have declined. A recent paper by Neveu (under publication), for example, reports that in the small Jordanian town of Ma'an, famous saints - notably women saints - were visited and venerated until the 1970 but are nowadays only vaguely remembered through oral literature and no longer benefit from any type of religious ritual.

Although shrines devotion survives in certain areas, regular individual and collective ziyara-s, whether in cities or villages, are not generally as frequent as they were forty or even twenty years ago. As El Ayadi, Rachik and Tozy (2002) show in their important work on religious practice in Morocco, many urban or rural families no longer practice holy visits as part of their regular religious obligations. To many families, a ziyara is nowadays synonymous with an extraordinary family or individual event, such as the preparations for a 
wedding, where the future bride is presented to the saint to be granted protection in her future life as a full woman (both wife and mother), or where a new born baby is introduced to the saint, or where there is a particularly difficult situation (grief due to the loss of a child, a close one or a job or a dire financial situation). Another occasion for a visit would be the return from hajj or umrah, when pilgrims bring presents for the saint in the shape of chandeliers, carpets or paintings. Where regular individual weekly visits do occur, they usually take place in two contrasting but connected contexts: weekly Sufi rituals or religious/therapeutic possession rituals (Andézian 1995, Boissevain 2006).

The decline in local pilgrimages has been partly due to the influence of reformist discourse and where governments have engaged in strategies such as the nationalization of habus or waqf during the 1960s in order to weaken religious brotherhoods. Nevertheless, they have survived in particular areas because they are embedded in local culture and heritage, especially in the Maghreb. Some have been drawn into the politics of regional culture where governments have not hesitated to incorporate them within national and international tourism strategies (which may include migrant workers and their families returning for summer holidays). For these moussem-s, the calendar may sometimes be changed and feasts, which were originally based on an agricultural calendar, may be moved to mid-summer for practical reasons. These changes have been observed since the early 1990s (Reysoo, 1991; Berriane, 1992) and have gathered momentum ever since, going as far as to modify the structure of the rituals through an increasing number of 'performance rituals' and a strong dose of folklorization. Despite some official religious condemnation, the evolution and changes of these traditional religious practices are the result of a joint process, that of 'politicization' and 'heritagization', often under the wing of the Ministry of Religious Affairs and the Ministry of Tourism. 
As a consequence, over the last 20 years the Maghreb countries have introduced many renovation programs at shrines, and different countries have organized recurring festivals where local or national saints are the main focus, e.g. Hadra in Tunisia and the Festival des musiques sacrées in Fès. The process of heritagization is promoting a national or regional religious identity and the top-down mobilization of folklore. At the same time, 'ordinary' religion lives within this religious modality without thinking twice about its cultural dimension. Of course, no 'popular culture' is independent of the national or global cultural and political context, but the renewal of religious sociability around holy shrines in rural and urban areas is a reality. Therefore, the recent visibility or renovations of saints' shrines must not only be interpreted solely in terms of heritagization policies.

\section{Pilgrimage, religious tourism and economy}

In the past forty years in anthropology, a distinct field of scholarship has been concerned with tourism, but few studies have yet analyzed the relationship between religious mobility and tourism in this region. Very recent research (some still in process) in the Middle East shows how tourism with a religious motivation is of great concern to nation-states. For instance, Norig Neveu (2013) documents how in Jordan since the 1990s the late King Hussein and his

son, King Abdullah II, have rebuilt mausoleums of pre-Islamic prophets and the Companions of Prophet Muhammad all over country, especially along the Jordan Valley. These reconstructions have been used as memorial sites for the monarchy and have led to the sacralization of the Jordanian national territory as part of an Islamic Holy Land. Yet as Neveu notes: 'The renovated sites have become today, in the eyes of the monarchy, representative of islamic heritage. Whereas they were initially used by local population, they tend today to welcome Muslim tourists from the whole world' (2010). 
In addition to the political strategy, the economic dimension is very present, with the increase of siyyaha el dinniyah (religious tourism) in the region. In the south of the Jordan territory, Marc Dugas is analyzing the emergence of a spectacular new religious site for his doctoral research. Since the beginning of 2000, the Jordanian authorities have been developing an 'authentic Jesus baptism site’ on the Jordan river, almost facing the Israeli site. The ambition is to transform this site into a major Christian pilgrimage and religious tourism center, which could have a positive economic impact on the region. These examples show how strongly political religious tourism can be and this is brilliantly brought to light by Jackie Feldman when he underlines the ways in which narratives concerning pilgrimage in Israel are shaped according to the pilgrim's religion. While the discourse is about a shared Biblical territory, practices vary considerably according to religion of the pilgrim/tourist/visitor (Feldman 2007).

As these examples remind us, commerce, knowledge and religion can be closely associated. In a Christian context, Claverie (2003) has shown how the small town of Medjugorje in Bosnia Herzegovina has developed into an international pilgrimage center with a thriving economy. Further east, Chatelard has also underlined the radical economic changes in the cities of Najaf and Karbala in Iran following the recent development of Shi'a pilgrimage to these cities.

\section{The increase of international travel and changes in pilgrimage}

As we have already mentioned, comparison between studies of Muslim pilgrimages shows how visits to shrines are linked to the Great Pilgrimage to Mecca through practices, discourses and symbols. In places very distant from Mecca, many important shrines may be called 'the poor person's Hajj'. Nevertheless, with the democratization of travel and the relative ease with which many pilgrims can now organize a plane trip, this relation between the holy land 
of Islam and smaller more peripheral shrines seems to be taking on a new dimension through the development of religious package tours. Indeed, religious package trips have long existed and travel agents have been searching for ways to keep the pilgrim/customer longer. The Hajj itself only lasts five days for the mandatory rituals but most pilgrims spend longer on site. The Hajj is therefore often a special time, extended by the possibility of visiting other holy places in Saudi Arabia, such as Mohamed’s bithplace in Medina.

In the last ten years changes have been introduced which make pilgrimages in the Middle East, whether they be Muslim, Christian or Jewish, similar in their touristic features. The general idea is to offer a larger package than simply a return ticket to Mecca. The package is more specifically tailored for a segment of believers, pilgrims or visitors, includes other significant destinations and enhances the feeling of the 'once in a life-time experience'. Hence, Senegalese travel agents offer trips to Mecca which may include a stop in Fès, which enable their Tijâni pilgrims from Dakar to pay a religious visit to the zawiya of Sîdî Ahmed el Tijâni, the founder of their tariqa, (Lanza 2014). Another frequent destination is Jerusalem, Islam’s third most holy city. Despite the political situation and some Muslim voices opposing visits to Jerusalem while it remains under Israeli occupation, the city is often included in the trip on the way to or back from Mecca (Grugeon 2015). It can be argued that this trend renews, albeit with a different, contemporary rhythm, the pre-flight travelling practice of visiting cities of important religious interest along the way to Mecca, as described by Chiffoleau (2015).

It should be underlined that the inclusion of secondary holy sites in religious package tours can only be sustained if the holy sites themselves are renovated and maintained. Governments throughout the region are investing in and restoring their religious architecture and are making the large pilgrimage sites accessible to as many pilgrims as possible. A paradoxical case is that of Mecca itself. Indeed, in radical opposition to this logic, the Saudi 
government is increasing its possibility of welcoming visitors and in the process undertaking an important destruction of sites of historical or religious importance. The major developments in Mecca and Medina follow the logic of 'purifying' the site of bida' (religious innovation), such as visits to the Prophet or to Ahl el Bayt, the Prophet's family. This entails important changes with regard to its relation to the past and the city's religious history.

At the same time, secondary places of worship are seeing the number of visitors increase considerably. To the example I have mentioned of Sîdî Ahmed el Tijâni in Fès, which is visited by Senegalese from Senegal as well as from France and by Moroccan pilgrims from Morocco or Europe, we could add many more, such as the ziyara of the Boutchitchiya tariqa in Madagh (Morocco), which benefits from a direct Ryanair flight from Beauvais to Madagh, or the Sayyda Zeinab shrine in Damascus, which attracted Shi'a pilgrims from neighbouring Iran before the recent conflict (Mervin 1996).

\section{Conclusion}

This brief overview shows that anthropological research on various forms of pilgrimages in the Maghreb and Middle East has gradually moved from a strict interest in ritual practices and religious cosmogonies linked with colonial agendas to a focus on popular religion, mainly understood as partaking in the female religious world and associated with therapeutic and magical practices. More recently, it has broadened its focus to include the political and economic processes which affect these sanctuaries. These processes involve the marketplace and the crucial expansion of transport systems (see Bennafla 2005, Saghi 2010, Chiffoleau 2015). The study of pilgrimage today in this part of the world has to take into account international travel and the complex changes linked to the politics and practices of tourism.

In terms of religious practice the survival of contemporary saint veneration and pilgrimage is perceived by many as an archaic practice which is bound to disappear (and has 
been perceived as such since the late $19^{\text {th }}$ century reformists). However, nation-states in the Maghreb and Machreq have also encouraged people to visit the shrines as 'tourists' in order to valorize local, historically implanted Islam against an alien, 'fundamentalist' version of Islam. The pilgrims to Mecca I interviewed (Boissevain 2015) are totally aware of these doctrinal tensions: they respect Muslim saints while understanding that for 'orthodox’ Muslims there should be no intermediaries between God and the believer. Despite this knowledge, when in Medina, meters away from the man who received God's revelation, they report that it was highly frustrating for them not to be able to touch and caress the tombstone, to take in some of the baraka of the Prophet through contact, to sit in a corner of the sanctuary and reflect, meditate, pray, or simply be in co-presence of the man who represents Islam in all its variety, complexity, transcendence and humanity. Yet, even if this proximity is disapproved of and prevented in the holy city of Mecca, it is still entertained in other religious sites, which in part explains their continued survival and prosperity.

The opening of religious rituals towards tourism and heritage contributes to the economic success of the phenomenon. The financial contribution made by tourists, visitors and pilgrims sometimes helps to renovate a mosque or sanctuary and encourages some of the religious performances. Consequently, under certain conditions, tourism strengthens the religious realm. Pilgrimage practices and religious tourism can be understood as new practices, which are transforming contemporary religion - a development which Danièle Hervieu-Léger, for example, noted in the context of France some twenty years ago (1993).

\section{References}

Albera, Dionigi et Couroucli, Maria (dir.), Religions traversées. Lieux saints partagés entre chrétiens, musulmans et juifs en Méditerranée, Arles, Actes sud, 2009.

Amir-Moezzi, Mohammed- Ali (dir.), Lieux d'islam. Cultes et cultures de l'Afrique à Java, Paris, Éditions Autrement, 1996. 
Amri, Nelly et Gril, Denis (dir.), Saint et sainteté dans le christianisme et l'islam. Le regard des sciences de l'homme, Paris, Collection L'atelier méditerranéen, Maisonneuve \& Larose MMSH, 2007

Andézian, Sossie, "Femmes et religion en islam : un couple maudit ? », in C. Leduc et A. Fine (dir.), «Femmes et religions », Clio, Histoire, Femmes et Sociétés, n² 2. 1995, http//clio.revues.org/document493.html.

Andézian, Sossie, Expériences du divin dans l'Algérie contemporaine. Adeptes des saints de la région de Tlemcen, Paris, CNRS Éditions. 2001

Aubin-Boltanski Emma, Pèlerinages et nationalisme en Palestine. Prophètes, héros, ancêtres, Paris, Édition de l’École des Hautes Études en Sciences Sociales, 2007.

Bennafla, Karine, « L’instrumentalisation du pèlerinage à La Mecque à des fins commerciales : l'exemple du Tchad » Chiffoleau, Sylvia, Madoeuf, Anna, Les pèlerinages au Maghreb et au Moyen-Orient. Espaces publics, espaces du public, Damas, IFPO, 2005

Berriane, Mohamed, Tourisme national et migrations de loisirs au Maroc, étude géographique, publications de la Faculté des Lettres et des Sciences Humaines, Rabat, Série Thèse et Mémoires, ${ }^{\circ} 16,1992$.

Boissevain, Katia, Sainte parmi les saints. Sayyda Mannûbiya ou les recompositions cultuelles dans la Tunisie contemporaine, Paris, Maisonneuve et Larose, coll. Connaissance du Maghreb, 2006.

Boissevain, Katia, « Preparativi per un pellegrinaggio alla Mecca : Organizzazione statale et transazioni domestiche in Tunisia », in D. Albera, M. Blanchard (dir.) Pellegrini del nuovo millennio. Aspetti economici et politici delle mobilità religiose, Messina, Mesogea, (Coll. Studi \& Ricerche), 2015, p. 247-268.

Bousquet, George Henry et Schacht, Joseph Oeuvres choisies de C. Snouck Hurgronje, Leiden, E.J. Brill, 1957

Brown Peter, Le culte des saints : son essor et sa fonction dans la chrétienté latine, Paris, Le Cerf, 1984.

Buitelaar, Marjo and Luitgard Mols (eds.), Hajj Global Interactions through Pilgrimage, Sidestone Press, Leiden, 2015

Burckhardt, John Lewis, Travels in Arabia, 1822.

Burton, Richard, F. Personal narrative of a Pilgrimage to Al Medinah and Meccah ,1855 New-York, Dover Publication, 1964

Chabbi, Jacqueline, « Ribât », Encyclopédie de l’islam, t. VIII, Leiden, E.J. Brill, nouvelle édition, 1995 p. 510-523. 
Chambert-Loir, Henri and Guillot, Claude (eds.), Le culte des saints dans le monde musulman, Paris, École française d’Extrême-Orient,1995.

Chiffoleau, Sylvia, Madoeuf, Anna, Les pèlerinages au Maghreb et au Moyen-Orient. Espaces publics, espaces du public, Damas, IFPO, 2005.

Chiffoleau, Sylvia, Le voyage à La Mecque. Un pèlerinage mondial en terre d'Islam, Paris, Belin, coll. « Histoire », 2015, 2015

Chih, Rachida, Le soufisme au quotidien. Confréries d'Égypte au XXe siècle, Paris, Actes Sud, 2000.

Chodkiewicz, Michel, «La sainteté féminine dans l'hagiographie islamique », in D. Aigle (dir.), Saints orientaux, Paris, Éditions de Boccard, 1995, p. 99-115.

Claverie, Elisabeth, Les guerres de la vierge. Une anthropologie des apparitions, Paris : Gallimard, « NRF Essais », 2003.

Crapanzano, Vincent, The Hamadsha. A Study in Moroccan Ethnopsychiatry, Berkeley : Los Angeles, University of California Press, 1973.

Depont, Octave et Coppolani, Xavier, Les confréries religieuses musulmanes, Alger, Librairie Adolphe Jourdan,1897.

Dermenghem, Émile, Le culte des saints dans l'Islam maghrébin, Paris, Gallimard, 1982 (1954).

Dugas, Marc, oral contribution : « Le site du baptême de Jésus en Jordanie. Un lieu de pèlerinage entre fondation et patrimonialisation» in K. Boissevain and N. Neveu, Le tourisme religieux dans le monde arabe : Entre pratiques pèlerines et enjeux patrimoniaux, 18 et 19 novembre 2015, Ifpo, Amman, Jordan.

Dwyer, "Women, sufism, and decision-making in Moroccan islam », Women in the muslim world. Beck L., Keddie N.(eds). U.S.A, Harvard University Press : 1979 585-598.

Eickelman Dale F. et Piscatori James, Muslim Travellers: Pilgrimage, Migration and the Religious Imagination, Londres, Routledge, 1990.

ElAyAdI, Mohammed, RACHIK, Hassan, Tozy, Mohamed, L'Islam au quotidien. Enquête sur les valeurs et les pratiques religieuses au Maroc, Casablanca, Prologues, coll : Religion et société, 2007.

Feldman, Jackie, “Constructing a Shared Bible Land: Jewish-Israeli Guiding Performances for Protestant Pilgrims”, in American Ethnologist 34, p. 349-372, 2007.

Geertz, Clifford, Islam Observed, New-Haven, Yale University Press, 1968.

Gellner, Ernest, Saints of the Atlas, Chicago, University Press of Chicago, 1969. 
Geoffroy, E. Le soufisme en Syrie et en Egypte sous les derniers Mamelouks et les premiers Ottomans. Orientations spirituelles et enjeux culturels, IFEAD, Damas, 1995.

Green Arnold H., The Tunisian Ulama, 1873-1915, Social Structure and Response to Ideological Currents, Leyde, Brill. 1978.

Goldziher I., «Veneration of saints in islam », in Stern S. M. (éd.) Muslim Studies, II, Chicago-New York, Aldine-Atherton, p. 255-341, 1971.

Hammoudi, Abdellah, Une saison à la Mecque, récit de pèlerinage, Paris, Le Seuil, 2005 .

Hervieu-Léger, Danièle, La religion pour mémoire, Paris, le Cerf, 1993.

Grugeon, Elsa, oral contribution : «Visiter ou non la mosquée al-Aqsa à Jérusalem : enjeux de la mise en tourisme d'un lieu saint en contexte coercitif » in K. Boissevain and N. Neveu, Le tourisme religieux dans le monde arabe : Entre pratiques pèlerines et enjeux patrimoniaux, 18 et 19 novembre 2015, Ifpo, Amman, Jordan.

Jamous, Raymond, 1981, Honneur et baraka : les structures sociales traditionnelles dans le Rif, Paris, Éditions de la MSH.

Jong, de, Fred, 1976, "Cairene Ziyara days. A contribution to the study of saint veneration in Islam”, Die Welt des Islam, t. 17, 26-43.

Kerrou, Mohamed, L'autorité des saints. Perspectives historiques et socio-anthropologiques en Méditerranée occidentale, Paris, Édition recherche sur les Civilisations, 1998.

Lakhdar, Latifa, 1998, « Réformisme et maraboutisme dans la Tunisie du début du XXe siècle», in M. Kerrou (dir.), L'autorité des Saints. Perspectives historiques et socioanthropologiques en Méditerranée occidentale, Paris, Éditions Recherches sur les civilisations, 323-333.

Lane, E. W. An Account of the Manners and Customs of Modern Egyptians, J. M. Dent, London, 1963 (1836).

Lanza, Nazarena, "Pèleriner, faire du commerce et visiter les lieux saints : le tourisme religieux sénégalais au Maroc" in S. Bava et K. Boissevain, Routes migratoires africaines et dynamiques religieuses, quels enjeux sociaux ? in L'Année du Maghreb, Paris, CNRS Editions, nº11, 2014, 159-172.

Luizard Pierre-Jean, « Un mawlid particulier », Égypte/Monde arabe, Le Caire, CEDEJ, n 14, 1993, 79-102.

Macpherson, J.W., The Moulids of Egypt, Le Caire, 1941.

Madoeuf Anna, 1997, Images et pratiques de la ville ancienne du Caire : le sens de la ville, thèse de doctorat en géographie, Université de Tours. 
Mayeur-Jaouen, Catherine, «Coupoles et minarets d'Egypte », in Amir-Moezzi, MohammedAli (dir.), Lieux d'islam. Cultes et cultures de l'Afrique à Java, Paris, Éditions Autrement, 1996, p. 114-131.

Mayeur-Jaouen, Le mouled de Tantâ du XIIIe siècle à nos jours, Aubier, 2004.

Mayeur-Jaouen, Pèlerinages d'Égypte, Histoire de la piété copte et musulmane (XVe-XXe siècles), Recherches d'histoire et de sciences sociales, 107, Éditions de l'EHESS, 2005.

Mayeur-Jaouen, Catherine, « Le culte des saints musulmans à la lumière d'Ignace Goldziher », in Céline Trauttmann- Waller (dir.), Ignac Goldziher : un classique de l'orientalisme ou un autre orientalisme ? Paris, Geuthner, 2011, p. 149-178.

Mernissi, Fatima, “Women, saints and sanctuaries”, Signs, vol. 3, 1977, p. 101-112.

Mouliéras, Auguste, Le Maroc inconnu. Étude géographique et sociologique, Paris, Challamel, 1899.

Neveu, Norig, " La sacralisation du territoire jordanien », Reconstruction des lieux saints nationaux, 1980-2006 in, Archives de sciences sociales des religions, vol. 3, $\mathrm{n}^{\circ} 151$, 2010, 107-128.

Popovic, Alexandre et veinstein Gilles (dir.), Les voies mystiques d'Allah. Les ordres mystiques dans le monde musulman des origines à aujourd'hui, Paris, Fayard, 1996.

Provensal, Danièle, « Le phénomène maraboutique au Maghreb », Genève-Afrique 14 : 1, p. 59-77, 1975

Reysoo, Fenneke, 1991, Pèlerinages au Maroc, Neuchâtel : Paris, Institut d’Ethnologie : Éditions de la MSH.

Rinn, Louis, 1884, Marabouts et khouan : étude sur l'islam en Algérie, Alger, Librairie Adolphe Jourdan.

Saghi, Omar, Paris-La Mecque : sociologie du pèlerinage, Paris, PUF, 2010,

Tapper, Richard and Nancy, "The Birth of the Prophet: Ritual and Gender in Turkish Islam", Man, New Series, Vol. 22, No. 1 Mar., 1987, pp. 69-92. 